ELKOM, Vol.12, No.2, Desember 2019, pp. 83 - 88

p-ISSN: 1907-0012

e-ISSN : 2714-5417

http://ejurnal.stekom.ac.id/index.php/home

- page 83

\title{
DESAIN SISTEM PENDATAAN KEHADIRAN KARYAWAN TERINTEGRASI FINGERPRINT DENGAN FUNGSI PENGATURAN SHIFT KERJA BERBASIS VISUAL
}

\author{
Ahmad Zainudin ${ }^{1}$, Lutfil Hakim Arif Efendi ${ }^{2}$ \\ ${ }^{1}$ Progdi Desain Grafis - Sekolah Tinggi Elektronika dan Komputer, \\ zaenudin@gmail.com \\ ${ }^{2}$ Progdi Sistem Komputer - Sekolah Tinggi Elektronika dan Komputer, \\ lutfilhakimarif@gmail.com
}

Jl. Majapahit 605, Semarang, telp/fax : (024) 6723456

\begin{tabular}{l}
\hline ARTICLE INFO \\
\hline Article history: \\
Received 19 Sep 2019 \\
Received in revised form 23 Sep 2019 \\
Accepted 25 November 2019 \\
Available online 13 Desember 2019
\end{tabular}

\begin{abstract}
Data collection on employee attendance at a company is a must, with the aim of monitoring discipline, calculating employee salaries, and other needs. Data collection on employee attendance at companies that are used today is very diverse, following the development of technology. The United Tronik Semarang office, which employs relatively many employees, currently uses a manual card attendance data collection system that attracts researchers to make the United Tronik Office the object of research.

Fingerprint is one of the hardware used to support employee attendance data collection which is relatively simple and easy to reach, the accuracy and ease of operation make the fingerprint attendance system more and more in demand. One of the human error problems in the attendance data collection system is attendance recording errors, especially for employees with shift work hours. Arrangement of work shifts in programs built with Visual Basic 2010 can minimize attendance recording errors, because it can set the recording time for employees. To support the ease of data access and shift settings, the researcher uses a Client Server database system with SQL Server 2005 Software.
\end{abstract}

Keywords: Attendance data collection, Fingerprint, Client Server

\footnotetext{
Abstrak

Pendataan Kehadiran Karyawan pada suatau perusahaan adalah suatu keharusan, dengan tujuan untuk memantau kedisiplinan, perhitungan gaji karyawan, dan kebutuhan- kebutuhan lainya. Pendataan kehadiran karyawan pada perusahaan - perusahaan yang digunakan saat ini sangat bermacam - macam mengikuti yang tentunya perkembengan teknologi. Kantor United Tronik Semarang yang mempekerjakan karyawan yang relatif banyak saat ini menggunakan sistem pendataan kehadiran kartu manual yang menarik peneliti untuk menjadikan Kantor United Tronik sebagai objek penelitian.

Fingerprint adalah salah satu hardware yang digunakan untuk perangkat pendukung pendataan kehadiran karyawan yang relatif sederhana dan mudah dijangkau, akurasi dan kemudahan dalam pengoperasianya mejadikan sistem absensi fingerprint semakin banyak peminatnya. Salah satu masalah human error pada sistem pendataan kehadiran adalah kesalahan pencatatan kehadiran, terutama pada
}

Received sep 19, 2019; Revised Nov 23, 2019; Accepted Desember 25, 2019 
karyawan dengan jam kerja shift. Pengaturan shift kerja pada program yang dibangun dengan Visual Basic 2010 dapat meminimalis kesalahan penctatan kehadiran, karena dapat mengatur waktu pencatatan pada karyawan. Untuk mendukung kemudahan akses data dan pengaturan shift peneliti menggunakan sistem database Client Server dengan Software SQL Server 2005.

Kata Kunci: Pendataan kehadiran, Fingerprint, Client Server

\section{Pendahuluan}

Teknologi pemindai sidik jari juga digunakan dala sistem pendataan kehadiran atau di indonesia sering di sebut dengan absensi. Absensi sidik jari saat ini sudah digunakan di banyak perusahaan karena berbagai macam hal, beberapa diantaranya adalah kemudahan cara pemakaian dan akurasi data yang lebih terpercaya. Seiring berjalannya waktu pendataan kehadiran karyawan memiliki sistem tersendiri mulai dari sistem pendataan kehadiran pencatatan manual, pendataan kehadiran kartu manual, pendataan kehadiran kartu digital, pendataan kehadiran fingerprint serta sistem pendataan kehadiran retina mata. dari beberapa macam sistem pendataan kehadiran tersebut yang paling efektif dan user friendly adalah fingerprint, cara penggunaannya sangat mudah dengan hanya menempelkan salah satu jari tangan ke finger scannernya sistem sudah dapat membaca sidik jari dari masing - masing individu. Data pendataan kehadiran dari sistem pendataan kehadiran fingerprint pun sudah berupa file yang siap di rekap di divisi HRD perbulannya untuk data kedisiplinan karyawan maupun untuk data penggajian.

United Tronik yang berada di jalan Batan Selatan No. 54 Semarang Tengah Kota Semarang, adalah perusahaan retailer pulsa yang berdiri sejak tahun 2009. United Tronik memiliki beberapa kantor cabang yang masih berada di kota Semarang. Sebagai perusahaan yang menyediakan jasa agen pulsa all operator, United Tronik tentu saja membutuhkan SDM yang produktif disiplin dan berkualitas. Sistem pendataan kehadiran karyawan di United Tronik yang menjadi salah satu indikasi kedisiplinan karyawan saat ini masih menggunakan sistem pendataan kehadiran kartu manual, sistem pendataan kehadiran ini berbentuk jam dengan lubang kartu di atasnya yang berfungsi untuk pencatatan pendataan kehadiran berdasarkan jam kedatangan karyawan dengan cara memasukan kartu kedalam lubang yang terdapat di atas mesin pendataan kehadiran. Berdasarkan informasi yang penulis dapatkan dari staff HRD United Tronik pada bulan Maret 2015, saat ini United Tronik mempekerjakan 52 karyawan pada kantor pusat yang terbagi dibeberapa divisi dengan jam kerja shift dan non shift.

Data pendataan kehadiran sebagai salah satu komponen perhitungan pembayaran gaji. Pembayaran gaji atau upah untuk karyawan di United Tronik dilakukan setiap tanggal 28, dengan perhitungan hari kerja tanggal $26 \mathrm{~s} / \mathrm{d}$ tanggal 25 bulan berikutnya. Dari data tersebut dapat disimpulkan bahwa divisi HRD hanya mempunyai waktu 3 hari untuk menghitung gaji semua karyawan berdasarkan data dari pendataan kehadiran. Karena sistem panggajian karyawan di United Tronik, selain gaji pokok juga berpacu pada kehadiran, ketepatan waktu, bonus penjualan, dan lain - lain, divisi HRD membutuhkan waktu yang relatif tidak sedikit untuk menghitung gaji dari semua karyawan perusahaan, karena hal tersebut seringkali divisi HRD mengambil jam tambahan atau lembur untuk menyelesaikan perhitungan gaji karyawan supaya pembayaran upah tepat waktu. Pendataan yang memakan waktu paling banyak ketika perhitungan gaji karyawan adalah pencatatan dan rekap pendataan kehadiran karyawan, hal tersebut dikarenakan pemindahan data dilakukan secara manual dari kartu pendataan kehadiran ke file excel pada komputer.

\section{Landasan Teori}

1. Analisa dan Perancangan Sistem Informasi

Sebuah sistem adalah suatu himpunan komponenatau variabel yang terorganisasi, saling berinteraksi, saling bergantung, satu sama lain dan terpadu. (Lucas, 1993)

Menurut Mcleod (2001), Sistem Informasi merupakan sistem yang mempunyai kemampuan untuk mengumpulkan informasi dari semua sumber dan menggunakan berbagai media untuk menampilkan informasi.

Perancangan Sistem dapat didefenisikan sebagai penggambaran, perencanaan, dan pembuatan sketsa atau pengaturan dari beberapa elemen yang terpisah kedalam satu kesatuan yang utuh dan berfungsi. Menurut Jogiyanto H.M (2001).

2. Pendataan Kehadiran

Menurut Pohan (2003) pendataan kehadiran didefinisikan sebagai berikut : "pendataan kehadiran adalah bukti kehadiran pekerja di tempat kerja, pekerja wajib untuk melaksanakan sendiri pencatatan

ELKOM Vol. 12, No. 2, Desember 2019: $83-88$ 
waktu hadirnya pada mesin pencatat waktu (amano) dan tanda tangan baik pada saat masuk bekerja dan pada saat meninggalkan tempat pekerjaan".

3. Shift Kerja

Shift kerja merupakan pola waktu kerja yang diberikan pada tenaga kerja untuk mengerjaka sesuatu oleh perusahaan dan biasanya dibagi atas kerja pagi, sore dan malam. (Suma'mur, 1994).

4. Fingerprint

Sidik jari atau fingerprint (dalam bahasa inggris) adalah pola pola guratan-guratan pada jari manusia. Pola pola sidik jari manusia dibentuk sejak usia empat bulan. Ridge atau pola garis yang menonjol pada jari manusia berkembang secara acak dan unik. Kecelakaan yang cukup fatal pada usia janin 4-7 bulan dapat mengubah pola sidik jari, menjelang usa 8 bulan dan seterusnya. Pola sidik jari yang sudah terbentuk tidak akan berubah sekalipun permukaan jari dibakar atau dipotong karena siteiap ridge sudah tertanam sampai pada kulit bagian dalam. (Kardiyanto dkk, 2003)

\section{Metodologi}

Model penelitian yang digunakan oleh penulis dengan menggunakan model pengembangan Research and Development (RnD) Soegiyono (2008:407), berpendapat bahwa metode penelitian dan pengembangan metode penelitian yang digunakan untuk menghasilkan produk tertentu dan menguji keaktifan produk tersebut. Untuk menghasilkan produk tertentu dugunakan penelitian yang bersifat analisis kebutuhan (digunakan metode survey atau kualitatif) dan untuk menguji keefektifan produk tersebut supaya dapat berfungsi di masyarakat luas, maka diperlukan penelitian untuk menguji keefektifan produk tersebut (digunakan metode eksperimen).

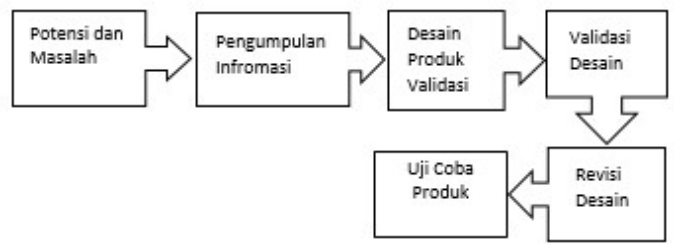

Gambar 1 Prosedur pengembangan metode R\&D

Untuk dapat memahami tiap langkah tersebut dapat dijelaskan sebagai berikut:

a. Potensi dan Masalah

Penelitian selalu bermula dari adanya potensi atau masalah. Potensi merupakan segala sesuatu yang jika didayaguakan akan mempunyai nilai tambah. Masalah juga dapat diubah menjadi sebagai potensi, apabila peneliti bisa mendayagunakan masalah tersebut. Masalah akan terjadi bila ada penyimpanan, antara yang diharapkan dengan keadaan yang terjadi. Masalah ini bisa diatasi melalui R \& D yaitu dengan cara menelitinya, sehingga bisa ditemukan suatu model, sistem atau pola pengembangan terpadu yang efektif yang bisa dipakai untuk mengatasi masalah tersebut.

b. Pengumpulan Data dan Informasi

Sesudah pontensi dan masalah bisa ditunjukkan secara faktual dan up to date, langkah berikutnya adalah mengumpulkan berbagai informasi dan studi literatur yang bisa dipakai sebagai bahan guna merencanakan pembuatan produk tertentu yang diharapkan bisa mengatasi masalah tersebut. Studi ini ditunjukan guna menemukan konsep - konsep maupun landasan - landasan teoritis yang bisa memperkuat suatu produk, misalnya produk yang berbentuk program, model, sistem, software, pendekatan, dan sebagainya. 


\subsection{Perancangan Sistem}

1. Flow of Document Sistem Baru

Tabel 1. Flow of Document Sistem Baru

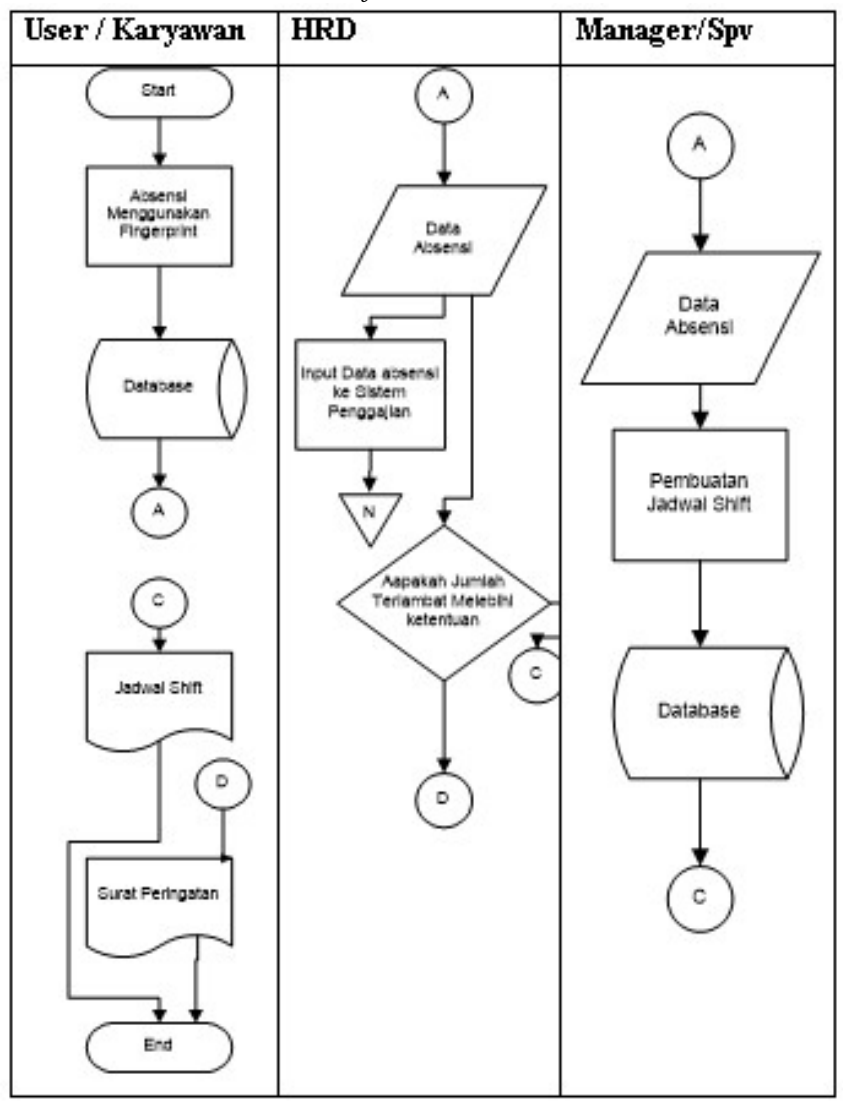

2. Data Flow Diagram

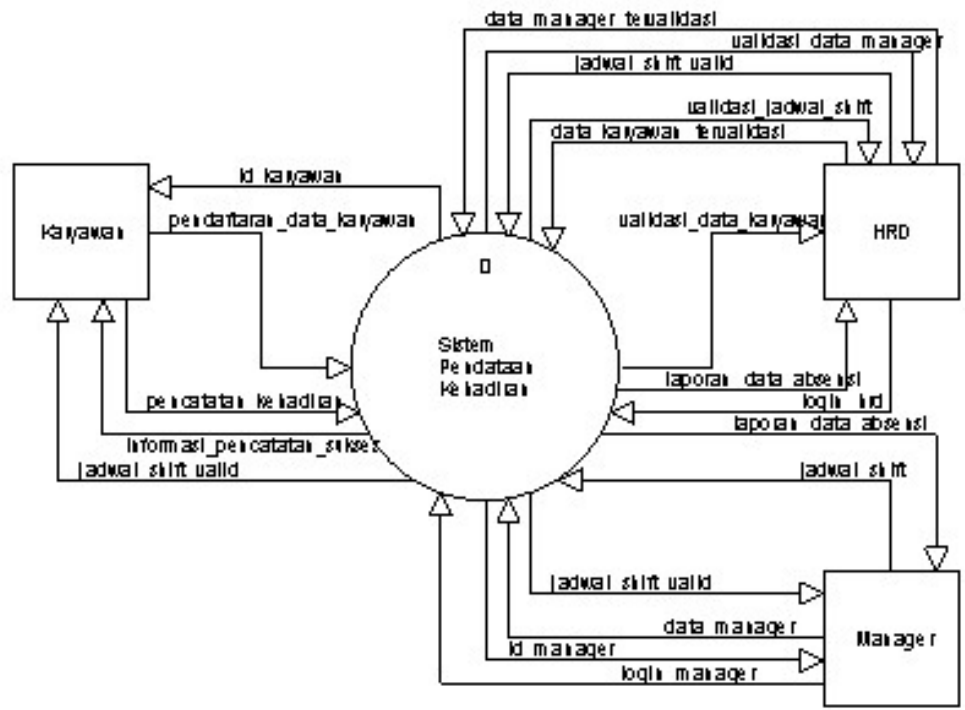

Gambar 3. Context Diagram

ELKOM Vol. 12, No. 2, Desember 2019: $83-88$ 


\section{Hasil dan Pembahasan}

Penelitian sistem pendataan kehadiran bertujuan sebagai untuk mengetahui kelebihan dan kelemahan sistem lama yang sudah sampai saat ini masih digunakan. Dengan mengetahui kelebihan dan kelemahan sistem, peneliti berharap dapat mengembangkan sistem pendataan kehadiran dengan lebih baik dari sistem yang sudah ada. Sistem pendataan kehadiran yang digunakan di kantor pusat United Tronik J1. Batan Selatan no.54 Semarang Tengah kota Semarang saat ini masih menggunakan kartu absensi dengan mesin analog untuk pencatatannya. Pencatatan kehadiran dengan menggunakan kartu absensi manual memiliki banyak kekurangan untuk sebuah mesin absensi jika dibandingkan dengan kemajuan teknologi saat ini. Beberapa kekurangan pada absensi kartu manual adalah kemungkinan kesalahan pencatatan data pada kartu karena kartu setiap karyawan bisa saja salah mencatatkan kartu atau justru sengaja mencatatkan lebih dari satu kartu, Input data secara manual ke komputer dari kartu absensi yang membutuhkan waktu dan kecermatan dari petugas HRD dan kesalahan jadwal untuk karyawan shift juga masih bisa terjadi pada sistem absensi kartu manual.

1. Form data kehadiran karyawan

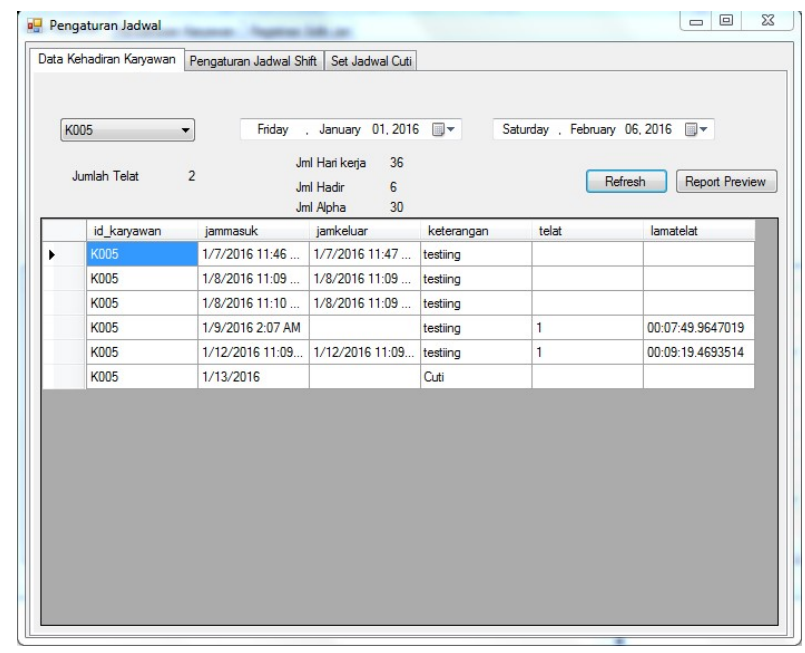

Gambar 4. Tampilan form kehadiran karyawan

\section{Kesimpulan}

Dari penjelasan yang telah diuraikan pada bab - bab sebelumnya, maka dapat ditarik kesimpulan sebagai berikut :

a) Uji Validasi yang telah dilakukan oleh pakar internal dan calon user sangat membantu peneliti untuk memperbaiki celah yang terdapat pada program yang peneliti kembangkan dan secara keseluruhan progam sudah layak digunakan.

b) Sistem pendataan kehadiran yang terintegrasi fingerprint lebih efektif dari segi cara pencatatan kehadiran dan cara pengolahan data, jika dibandingkan dengan sistem lama yang menggunakan sistem pencatatan kartu manual.

c) Sistem yang dibangun dengan sistem database client server dapat membantu user dari managerial perusahaan lebih mudah memantau data kehadiran karyawan setiap hari tanpa harus menunggu data daru divisi HRD 


\section{Daftar Pustaka}

Alan B, Sterneckert, 2003,"Critical Incident Management", boca raton florida: P. taylor \& francis group.

Al-Bahra bin Ladjamudin, 2005, “Analisis dan Desain Sistem Informasi”, Yogyakarta : Graha Ilmu.

Arbie, E, 2000, “Sistem Informasi Manajemen, Edisi Ke-7, Jilid 1”,Jakarta: Bina Alumni Indonesia.

Ashbaugh, David R. (1991) "Ridgeology”. Journal of Forensic Identification Vol 41 (1) ISSN: 0895-1 $73 \mathrm{X}$.

Borg And Gall, 1989,’Educational Research”, New York: Pinancing. $\quad$ Washington: The World bank.

Cakra, Kardianto and Adenan and Tandyo, Anny, 2003, "Sistem Pengenalan Sidik Jari Berdasarkan Karateristik Minutiae dan Jumlah Ridge Dengan Metode Backpropagation Jenis Nguyen Widrow”. Undergraduate thesis: Binus.

Chapple, Mike 2010, "Introduction to Microsoft SQL Server 2000", about tech, (http://databases.about.com/od/sqlserver/a/sqlserver2k.htm)

Djarendra, 2010, “Karyawan Adalah Modal Perusahaan”, (http://djajendra- motivator.com/?p=783).

Mcleod, Raymond, 2001,“ Sistem Informasi Manajemen”, Jakarta : PT. Prenhallindo

Microsoft Developer Network, 2015, "Visual Basic", Microsoft (https://msdn.microsoft.com/enus/library/2x7h1hfk.aspx)

Pohan, Husni Iskandar, 1997, “Pengantar Perancangan Sistem”, Jakarta: Penerbit Erlangga.

Pujiadi, 2013, "Penelitian Pendidikan Bergenre Research And Development (R\&D)", Widyaswara LPMP Jawa Tengah http://lpmpjateng.go.id/web/index.php/arsip/karya-tulis-ilmiah/839penelitian-r-a-d.

Seels, Barbara B. \& Richey, Rita C, 1994, "Teknologi Pembelajaran: Definisi dan Kawasannya." Penerjemah Dewi S. Prawiradilaga dkk. Jakarta: Kerjasama IPTPI LPTK UNJ.

Suma’mur P.K, 1994, “Higiene Perusahaan dan Kesehatan Kerja”, Jakarta: Haji Masagung.

Sugiyono, 2009, "Metode Penelitian Kuantitatif, Kualitatif dan R\&D", Bogor: Graha ilmu.

Suryanto, Suharli, 2005, "Membangun Aplikasi Berbasis Windows",

Tominarto, 2013, "Sistem Informasi Berbasis Fingerprint Untuk Meningkatkan Pelayanan Pendaftaran Pasien Rawat Jalan”, Infokes, Vol.3 No. 2 Agustus 2013. (ISSN : 2086-2628).

Wahana Komputer, 2006, "Menginstalasi perangkat jaringan komputer" Jakarta : Elex Media Komputindo.

Wahyono, Teguh, 2007, “Building \& Maintenaince Server”, Jakarta : PT Elex Media Komputindo.

Warman, Indra, Firdaus, Yogi, 2012, “Aplikasi Presensi Karyawan Menggunakan Barcode Slot Reader SLR-700IR”, Padang: Institute Teknologi Padang. (ISSN:2086-4981).

ELKOM Vol. 12, No. 2, Desember 2019: $83-88$ 